\title{
Insulin Suppresses Growth Hormone Secretion by Rat Pituitary Cells
}

\author{
Shlomo Melmed \\ Department of Medicine, Cedars-Sinai Medical Center-UCLA \\ School of Medicine, Los Angeles, California 90048
}

A

bstract. The effects of insulin on basal and hydrocortisone-induced growth hormone $(\mathrm{GH})$ secretion were studied in rat pituitary tumor cells $\left(\mathrm{GH}_{3}\right)$. Cells were grown in monolayer culture and exposed to exogenously added insulin for up to $8 \mathrm{~d}$. Basal GH secretion was inhibited by insulin $(0.7 \mathrm{nM})$ after a 48 -h lag period by $\sim 50 \% \quad(P<0.01$, vs. untreated control cells). The suppression of GH secretion was reversible, as removal of added insulin resulted in return of GH secretion to normal levels after $24 \mathrm{~h}$. Maximal suppression of basal GH secretion was achieved by $0.7 \mathrm{nM}$ insulin, and these effects were prevented by simultaneous exposure of the cells to guinea pig anti-insulin serum $(1: 2,000)$. No effects of insulin on cell replication were evident, and glucose concentration in the medium did not differ in control or insulin-treated wells. Insulin ( $7 \mathrm{nM})$ significantly suppressed the fivefold hydrocortisone-induced $\mathrm{GH}$ stimulation during $5 \mathrm{~d}$ of incubation with up to $1,000 \mathrm{nM}$ of the steroid $(P<0.001)$. These inhibitory effects were similarly observed in glucose- and pyruvate-free medium, and in the presence of 2-deoxyglucose. Insulin also reversed the suppression of prolactin (PRL) secretion induced by hydrocortisone (1 uM), and actually stimulated basal PRL secretion by over 50\%. Insulin did not alter the inhibitory effect of hydrocortisone on $\mathrm{GH}_{3}$ cell proliferation. Although higher doses (13 nM) of insulin-like growth factor (IGF-I) also suppressed basal GH secretion, IGF-I did not alter the GH and PRL secretory changes induced by hydrocortisone. The results show that insulin exerts a direct, specific inhibitory effect on basal and hy-

Dr. Melmed is the recipient of Clinical Investigator Award AM 00906 from the National Institute of Arthritis, Diabetes, Digestive and Kidney Diseases. 1984.

Received for publication 3 May 1983 and in revised form 5 January

\author{
J. Clin. Invest. \\ (c) The American Society for Clinical Investigation, Inc. \\ 0021-9738/84/05/1425/09 $\$ 1.00$
}

Volume 73, May 1984, 1425-1433

drocortisone-induced $\mathrm{GH}$ secretion by $\mathrm{GH}_{3}$ cells unrelated to glucose utilization by the cells.

\section{Introduction}

Although insulin and glucose play a significant role in the modulation of growth hormone $(\mathrm{GH})^{1}$ secretion $(1,2)$, specific action of insulin on the pituitary are difficult to demonstrate in vivo. The cellular effects of insulin include a rapid modulation of membrane-related transport systems, as well as a longer-term effect on regulation of gene expression and protein synthesis independent of its effects on glucose and amino acid transport (3-6). Insulin was shown to regulate carbohydrate metabolism in the rat anterior pituitary (7), but its role in directly modulating anterior pituitary hormone secretion generally, and GH specificially, has not been extensively studied. Pituitary GH content of rats rendered diabetic by alloxan was significantly lower than in nondiabetic rats (8). As pituitary GH content was inversely correlated with the severity of diabetes in these animals, a role for insulin in modulating $\mathrm{GH}$ synthesis was proposed (8). Although insulin stimulated new protein synthesis by the rat anterior pituitary during $3 \mathrm{~h}$ of in vitro exposure to the hormone (9), no specific effects on incorporation of radiolabeled precursor into GH or prolactin (PRL) were noted during this short treatment.

Recently, the presence of specific binding sites for insulin have been characterized on rat pituitary homogenatees (10), pituitary microsomal membranes (11), and rat pituitary tumor cells $\left(\mathrm{GH}_{3}, \mathrm{GH}_{1}\right.$, and $\left.\mathrm{GC}\right)(12,13)$. The dissociation constant $\left(K_{\mathrm{D}}\right)$ for insulin binding in these studies ranged from 2 to 0.3 $\mathrm{nM}$, which is of a similar order of magnitude seen in other insulin-responsive tissues (14). Biological effects of insulin on pituitary cell hormone secretion were not reported in these two preliminary studies $(12,13)$.

In view of the above findings, experiments were performed to further evaluate the effects of insulin on in vitro $\mathrm{GH}$ secretion. $\mathrm{GH}_{3}$ cells, a cloned rat pituitary tumor cell line secreting both

1. Abbreviations used in this paper: ANOVA, analysis of variance; dbCAMP, dibutyryl-cyclic AMP; GH, growth hormone, IGF-I, insulinlike growth factor-I; IGF-II, insulin-like growth factor-II; PRL, prolactin. 
GH and PRL, were used (15). The hormonal secretory patterns of these cells have been well characterized $(13,16)$. Hydrocortisone stimulates $\mathrm{GH}$ secretion in these cells $(17,18)$, and inhibits PRL secretion (19). The steroid causes increased GH messenger RNA (20-22) and GH gene transcription $(23,24)$. This response has also recently been confirmed in vivo (24), supporting the physiologic relevance of hydrocortisone-induced GH stimulation.

The studies reported here show that physiological concentrations of insulin suppress basal GH secretion and high physiologic doses inhibit the hydrocortisone-induced stimulation of $\mathrm{GH}$ by these cells.

\section{Methods}

Materials. Bovine pancreatic insulin and hydrocortisone were purchased from Sigma Chemical Co., St. Louis, MO, and guinea pig antibovine insulin serum from Miles Biochemicals, IN. Partially purified somatomedin (25) was kindly provided by Dr. Ron Rosenfeld, Stanford University. $1 \mathrm{mg}$ of this preparation contained $50 \mu \mathrm{g}$ insulin-like growth factor-I (IGF-I) and $22.7 \mu \mathrm{g}$ insulin-like growth factor-II (IGF-II) as measured by specific radioimmunoassay (RIA) $(26,27)$. Doses of somatomedin are expressed as IGF-I (nanograms per milliliter). Fetal calf serum was obtained from Sterile Systems, Logan, UT. Unless otherwise stated, cell culture materials were obtained from Irvine Scientific Co., Santa Ana, CA.

Cells. $\mathrm{GH}_{3}$ cells, a cloned line of rat pituitary tumor cells secreting GH and PRL (16), were obtained from the American Type Culture Collection, Rockville, MD. Cells were maintained in serial monolayer culture as described (28). The cells have been routinely grown in Ham's F10 medium supplemented with fetal calf serum $(2.5 \%)$, horse serum (15\%), glutamine ( $5 \mathrm{mM}$ ), and antibiotics (culture medium) in a humidified atmosphere of $95 \%$ air:5\% $\mathrm{CO}_{2}$. Glucose concentration, as measured by glucose oxidase method in a Beckman glucose analyzer (Beckman Instruments, Inc., Fullerton, CA), was $110 \mathrm{mg} / \mathrm{dl}$. Insulin concentration, determined by RIA (29), was undetectable $(<5 \mu \mathrm{U} / \mathrm{ml})$ in the culture medium.

For experiments utilizing glucose-free medium, cells were grown in deficient (glucose-free) Dulbecco's Modified Eagle medium enriched with dialyzed horse serum $(10 \%)$, glutamine $(10 \mathrm{mM})$, and antibiotics (glucose-free culture medium). This culture medium contained $<5 \mathrm{mg} /$ dl glucose. Sodium pyruvate $(10 \mathrm{mM})$ or 2-deoxyglucose $(20 \mathrm{mg} / \mathrm{dl})$ were added to glucose-free medium for some experiments.

Experimental procedure. All experiments were performed on cells obtained from the same parent culture flask $\left(75 \mathrm{~cm}^{2}\right.$, Costar, Cambridge, MA). Approximately 50,000 cells were seeded in Multiwell tissue culture plates ( $35 \mathrm{~mm}$ diameter, Costar) in $2 \mathrm{ml}$ of culture medium. Cells were either pretreated with insulin before seeding into experimental wells for the times indicated, or insulin and drugs were added immediately after seeding of cells. At the designated time intervals, medium was aspirated, centrifuged at $800 \mathrm{~g}$ for $10 \mathrm{~min}$, and frozen at $-20^{\circ} \mathrm{C}$ for hormone assay. Cells from each well were taken up in $2 \mathrm{ml}$ isotonic saline and counted in an Automatic Cell Counter (Coulter Electronics Inc., Hialeah, FL).

Insulin degradation. In order to assess the degradation of insulin under the culture conditions employed, exogenously added insulin was examined by TCA precipitability of ${ }^{125}$ I-labeled insulin. ${ }^{125}$ I-labeled insulin was prepared by enzymatic iodination using Enzymobead reagent (Bio-
Rad Laboratories, Richmond, CA) (30). More than 95\% of the radioactivity of ${ }^{125} \mathrm{I}$-labeled insulin $(80-100 \mu \mathrm{Ci} / \mu \mathrm{g} \mathrm{sp}$. act.) was precipitable by ice cold $12 \%$ TCA and was also recovered in the intact insulin peak when ${ }^{125}$ I-insulin was subjected to gel filtration over G-50 Sephadex. After $72 \mathrm{~h}$ of exposure to the cells in culture, $60 \%$ of media ${ }^{125} \mathrm{I}$-insulin was precipitable and $40 \%$ of the tracer was soluble in TCA. Therefore, in all experiments, $40 \%$ of the initial insulin dose was replenished after $72 \mathrm{~h}$ in order to maintain the required concentrations of the hormone.

RIAs. Rat GH was iodinated using chloramine $\mathrm{T}$ and sodium metabisulfate as described (31). More than $95 \%$ of the radioactivity was precipitable by TCA and was also recovered in the intact rat GH peak when subjected to gel filtration over G-75 Sephadex. Rat GH and PRL were measured by RIA using materials supplied by the National Pituitary Agency, National Institutes of Arthritis, Diabetes, Digestive and Kidney Diseases, Bethesda, MD. All samples from each experiment were assayed in the same RIA. Samples were assayed in duplicate with at least three dilutions in order to yield accurate extrapolations from the standard curve. Insulin was assayed by RIA (29). None of the medium or reagents employed in the experiments caused a cross-reaction in the RIAs used.

Statistics. Results are expressed as mean \pm SEM unless otherwise indicated. Differences were assessed by nonpaired $t$ testing, or two-way analysis of variance (ANOVA) with Scheffe's multiple comparison procedure (32).

\section{Results}

Insulin effects on $G H$ degradation. In order to test whether insulin altered the rate of extracellular degradation of $\mathrm{GH}$, cells were incubated in the presence of ${ }^{125} \mathrm{I}-\mathrm{GH}$ and insulin, and aliquots of medium were removed periodically to assess the TCA precipitability of the added tracer. $95 \%$ of ${ }^{125} \mathrm{I}-\mathrm{GH}$ present in the medium prior to incubation (zero-time) was precipitable after $96 \mathrm{~h}$ of incubation in wells not containing cells (cell-free). During this period, $80 \%$ of the zero-time tracer counts were precipitable when ${ }^{125} \mathrm{I}-\mathrm{GH}$ was incubated in wells containing $\mathrm{GH}_{3}$ cells growing in culture medium. There was no difference in stability of the ${ }^{125} \mathrm{I}-\mathrm{GH}$ in the presence of 0.7 and $7 \mathrm{nM}$ added insulin, as compared with control wells containing cells with no added insulin. Insulin therefore did not alter the degradation of $\mathrm{GH}$, at least as assessed by TCA precipitability of the ${ }^{125} \mathrm{I}-\mathrm{GH}$ tracer.

Basal GH secretion. Insulin did not inhibit GH hormone release in the medium during the first $24 \mathrm{~h}$ of incubation (Fig. 1 , insert). Basal GH secretion was inhibited by $0.7 \mathrm{nM}$ insulin over $50 \%$ during $48 \mathrm{~h}$ of incubation (Fig. 1, bottom). Even when a higher dose (7 $\mathrm{nM})$ of insulin was used, no inhibition of $\mathrm{GH}$ was seen during the first $24 \mathrm{~h}$ of incubation. This inhibition was significant throughout the 8-d duration of these experiments, with basal hormone secretion being suppressed by $40-50 \%$ at each time point. Using a higher dose of insulin ( $7 \mathrm{nM}), \mathrm{GH}$ secretion was further suppressed at each point. Fig. 1 shows data from a single representative experiment. Because of the wide inter-experimental variation in control and GH secretion, data from four separate experiments were pooled and expressed as a percentage of control values. After $48 \mathrm{~h}, \mathrm{GH}$ secretion was $61 \pm 2$ and $40 \pm 6 \%$ of controls in the presence of 0.7 and $7 \mathrm{nM}$ 


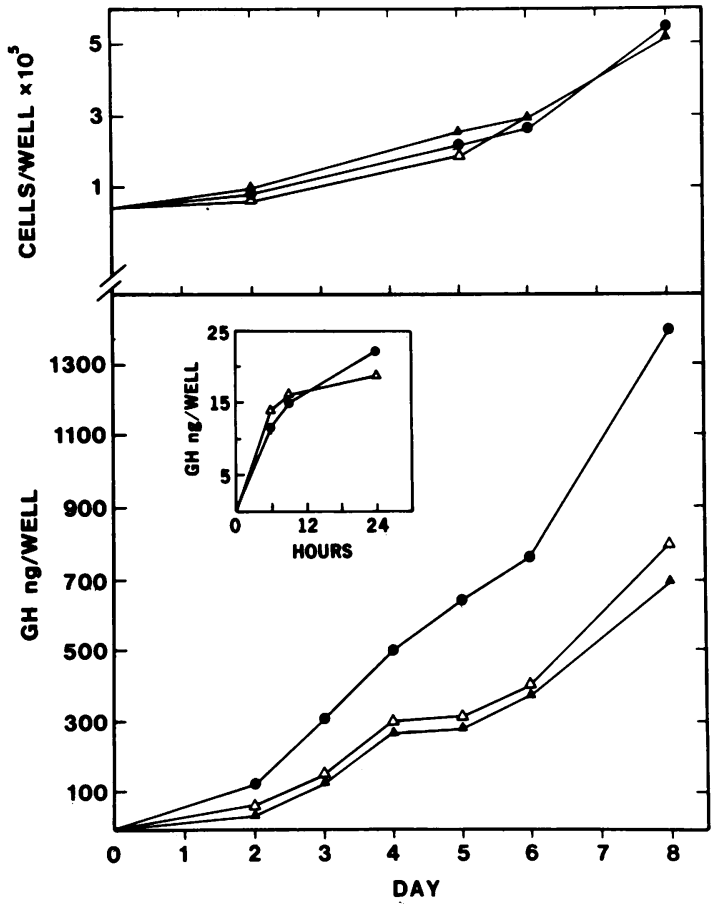

Figure 1. Time course of cell replication (top panel) and GH secretion (bottom) in presence of insulin. About $5 \times 10^{4}$ cells were incubated in 36 multiwells on day 0 in culture medium containing no added insulin (controls, $-\bullet-$ ), or insulin, $0.7 \mathrm{nM}(-\Delta-)$ or 7 nM $(-\Delta-)$. At each time point, medium from duplicate wells was aspirated for RIA, and cells counted. Insert shows the time-course for 0-24 h.

insulin, respectively. After $8 \mathrm{~d}, \mathrm{GH}$ suppression was similar in the two insulin-treated groups, $65 \pm 4$ and $63 \pm 4 \%$ of controls. No differences in cell number were observed in insulin-treated vs. untreated wells throughout $8 \mathrm{~d}$ of incubation (Fig. 1, top).

The reversibility of the inhibition of $\mathrm{GH}$ induced by insulin was tested by growing cells in the presence or absence of 0.7 $\mathrm{nM}$ insulin for $48 \mathrm{~h}$. Medium was then completely aspirated, fresh medium containing no added insulin was replaced in all the wells, and the incubations continued. Fig. 2 shows that inhibition of GH secretion by cells previously exposed to insulin was present for up to $24 \mathrm{~h}$ after insulin was removed; thereafter, secretion recovered to attain similar levels to those seen in cells which were previously not exposed to insulin.

The dose-responsiveness of basal GH suppression by insulin is shown in Fig. 3. Maximal suppression was achieved by 0.7 $\mathrm{nM}$ insulin. To confirm the specificity of the observed suppression of basal GH secretion, cells were incubated with insulin with and without guinea pig anti-insulin serum $(1: 2,000)$. Cells in control wells were also exposed to similar titers of antiserum. The suppression of basal GH secretion by $0.7 \mathrm{nM}$ insulin was neutralized by simultaneous exposure of cells to insulin antiserum (Fig. 4). Insulin antiserum alone, when added to control wells, did not alter basal GH secretion. Although the same titer

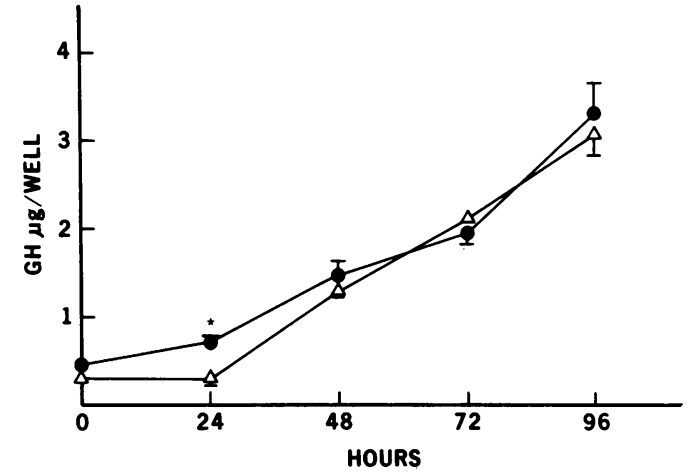

Figure 2. Recovery of $\mathrm{GH}$ secretion. $\mathrm{GH}_{3}$ cells $\left(\sim 10^{5}\right)$ were incubated in the absence $(-\bullet-)$ or presence $(-\Delta-)$ of insulin $(0.7$ $\mathrm{nM}$ ) for $48 \mathrm{~h}$ in $2 \mathrm{ml}$ of medium. At time 0 , medium was changed and replaced with fresh medium containing no added insulin, and in cubations continued for the indicated times. Each point represents mean of triplicate wells \pm SEM. After $24 \mathrm{~h}$, there was no subsequent difference between control and insulin-treated $\mathrm{GH}$ secretion $(P$ $<0.05$ ). Cell counts in treated and untreated wells were not different.

$(1: 2,000)$ antiserum was able to significantly reverse the suppression of $7 \mathrm{nM}$ insulin, GH secretion did not attain control, untreated values. A higher titer of guinea pig antiserum proved toxic to the cells and was therefore unable to be tested against the higher insulin dose (7 $\mathrm{nM})$.

Hydrocortisone effects. As hydrocortisone has previously been shown to stimulate $\mathrm{GH}$ secretion by $\mathrm{GH}_{3}$ cells $(17,18)$, the effects of insulin were tested on this response. For these experiments, $\mathrm{GH}_{3}$ cells were preincubated in the presence or

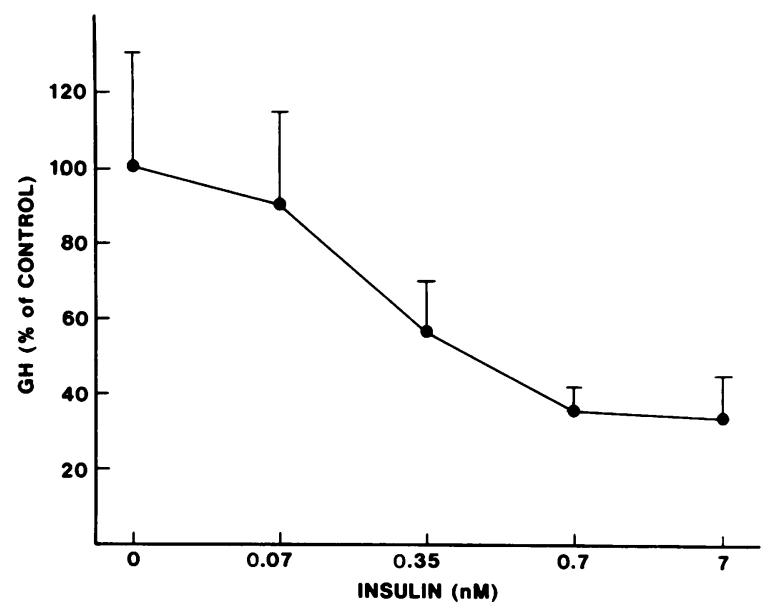

Figure 3. Dose-response of inhibition of GH secretion by insulin. Cells were incubated in the presence of the indicated doses of insulin for $48 \mathrm{~h}$. Data from four experiments were pooled and expressed as a percentage of $\mathrm{GH}$ secreted in control wells receiving no added insulin. Control wells secreted $995 \pm 299 \mathrm{ng} \mathrm{GH} / 10^{6}$ cells per $48 \mathrm{~h}$ (mean \pm SD). 


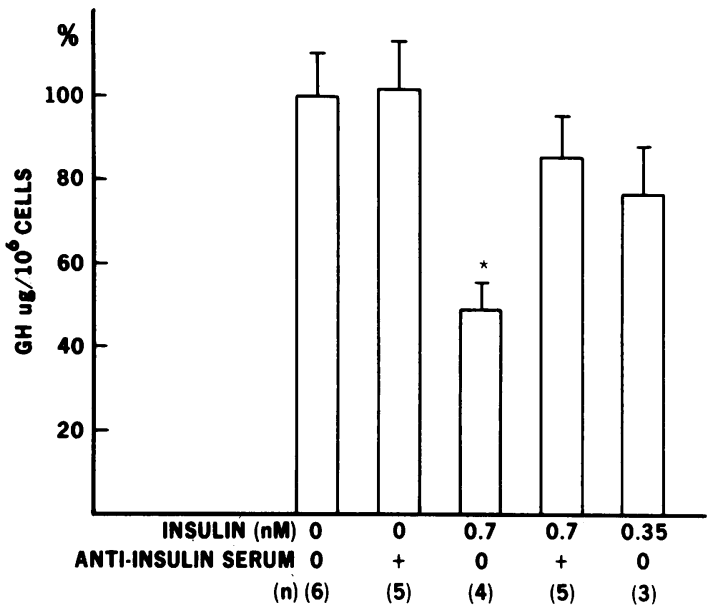

Figure 4. Effect of guinea-pig anti-insulin serum on GH secretion. $\mathrm{GH}_{3}$ cells were incubated for $48 \mathrm{~h}$ in medium with or without added insulin and/or insulin antiserum (mean \pm SEM). $*, P<0.01$ vs. controls and vs. insulin and antiserum.

absence of insulin for $48 \mathrm{~h}$, and then seeded into multiwells in the presence of hydrocortisone (0-1,000 nM). The same doses of insulin were used for the preincubations and the hydrocortisone-treated incubations. Fig. 5 shows that hydrocortisone (100 $\mathrm{nM}$ ) stimulated $\mathrm{GH}$ secretion fivefold during $5 \mathrm{~d}$ of incubation. By two-way ANOVA, the response to hydrocortisone was sig-

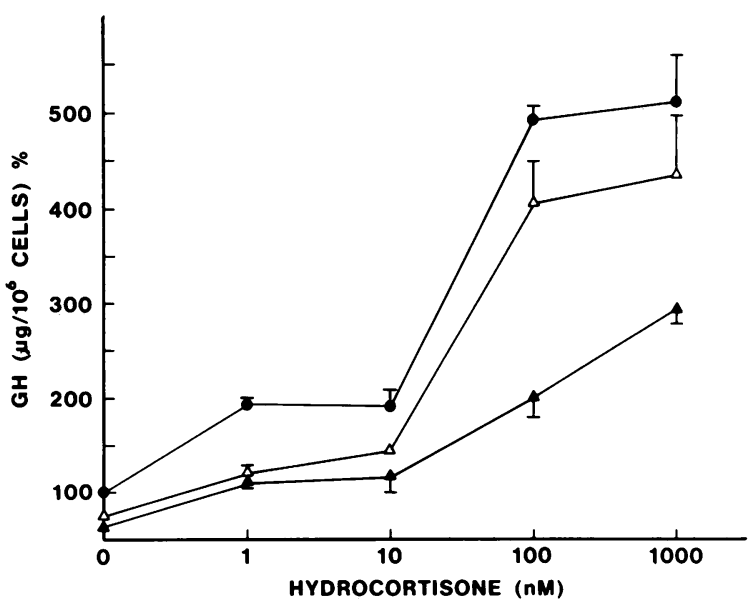

Figure 5. Effects of insulin on hydrocortisone-induced stimulation of GH secretion. $\mathrm{GH}_{3}$ cells were grown in culture medium without $(-\bullet-)$ or with added insulin, $0.7 \mathrm{nM}(-\Delta-)$ or $7 \mathrm{nM}(-\Delta-)$, for $48 \mathrm{~h}$ in $75 \mathrm{~cm}^{2}$ tissue culture flasks. About $4 \times 10^{4}$ cells were then seeded in 30 multiwells containing $2 \mathrm{ml}$ of medium without (control) or with added insulin, as well as the indicated concentrations of hydrocortisone. After $5 \mathrm{~d}$, medium was aspirated for RIA, and cells counted. Each point represents mean $( \pm$ SEM) of 4-6 wells pooled from two separate experiments. By two-way ANOVA, GH secretion in the wells treated with insulin, $7 \mathrm{nM}$, were significantly different from control wells $(P<0.001)$

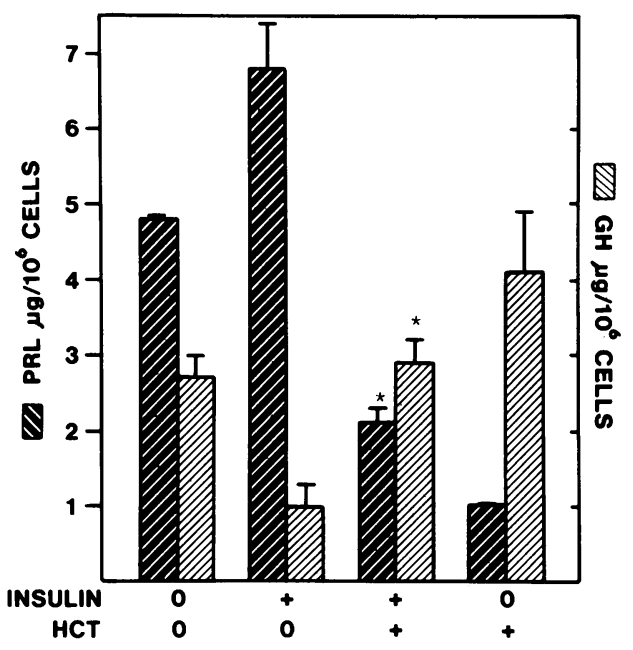

Figure 6. Effect of hydrocortisone $(H C T)$ on GH and PRL secretion by $\mathrm{GH}_{3}$ cells. Cells were incubated in multiwells for $5 \mathrm{~d}$ in the presence of HCT $(1 \mu \mathrm{M})$ and/or insulin $(0.7 \mathrm{nM})$, at which time medium was aspirated and cells counted. Each bar represents mean of triplicate wells $( \pm \mathrm{SD})$. Data are representative of a single experiment performed independently eight times. $(*, P<0.001$ vs. HCT alone or insulin alone).

nificantly inhibited at each dose tested by preincubation and simultaneous exposure of cells to $7 \mathrm{nM}$ insulin $(P<0.001)$. In the presence of insulin, $10 \mathrm{nM}$ hydrocortisone did not stimulate GH secretion, whereas $1 \mathrm{nM}$ hydrocortisone doubled GH secretion when no insulin was added. Insulin $(0.7 \mathrm{nM})$ was able to significantly suppress the stimulatory effect of up to $10 \mathrm{nM}$ hydrocortisone $(P<0.01)$. The higher dose of insulin $(7 \mathrm{nM})$ suppressed by half the $\mathrm{GH}$ stimulation seen with up to $1 \mu \mathrm{M}$ hydrocortisone. That this action of insulin was a specific antagonism to the steroid effect rather than a general cellular effect was further confirmed by the observation that the suppressed PRL secretion induced by hydrocortisone was also reversed by insulin (Fig. 6). Insulin stimulated both basal PRL secretion as well as the suppressed PRL secretion caused by hydrocortisone. The typical effects of insulin and/or hydrocortisone on GH secretion were also seen in these same cells.

Hydrocortisone clearly suppressed the growth of $\mathrm{GH}_{3}$ cells (Table I). Although insulin modulated the secretory response of the cell to hydrocortisone, it had no effect on the suppression of cell growth induced by the steroid. This further confirmed the specificity of the insulin effect on hormone secretion.

Relationship of glucose availability to the insulin effects. Glucose, in different concentrations, was added to the medium in order to assess whether the observed insulin effects on $\mathbf{G H}$ secretion were related to glucose availability and utilization by the cells. Cells pretreated with insulin for $72 \mathrm{~h}$ were cultured in the presence of three different starting concentrations of glucose $(110,160$, or $210 \mathrm{mg} / \mathrm{dl})$. After $4 \mathrm{~d}$ incubation, glucose was measured in the medium. Table II shows that medium glucose levels fell after $4 \mathrm{~d}$ in both treated and untreated wells. 
Table I. Effects of Hydrocortisone and Insulin on $\mathrm{GH}_{3}$ Cell Replication during $5 d^{*}$

\begin{tabular}{|c|c|c|c|c|c|c|c|}
\hline \multirow[b]{2}{*}{ Insulin } & & \multicolumn{6}{|c|}{ Hydrocortisone $(n M)$} \\
\hline & & 0 & 1 & 10 & 100 & 1000 & 10,000 \\
\hline & $n M$ & & & & & & \\
\hline \multirow[t]{2}{*}{ Experiment 1} & 0 & $4.5 \pm 0.9$ & $3.8 \pm 0.1$ & $3.3 \pm 0.1$ & $2.7 \pm 0.1$ & $2.2 \pm 0.1$ & $1.3 \pm 0.1$ \\
\hline & 0.7 & $3.9 \pm 0.4$ & $3.5 \pm 0.04$ & $2.9 \pm 0.1$ & $2.9 \pm 0.2$ & $2.1 \pm 0.04$ & $1.4 \pm 0.01$ \\
\hline \multirow[t]{2}{*}{ Experiment 2} & 0 & $2.6 \pm 0.2$ & $2.3 \pm 0.2$ & $2.0 \pm 0.18$ & $1.6 \pm 0.18$ & $1.6 \pm 0.04$ & \\
\hline & 7 & $2.5 \pm 0.05$ & $2.2 \pm 0.15$ & $2.4 \pm 0.1$ & $2.0 \pm 0.1$ & $1.6 \pm 0.09$ & \\
\hline
\end{tabular}

* $\mathrm{GH}_{3}$ cells were incubated for $5 \mathrm{~d}$ in the presence of hydrocortisone at the indicated doses with or without insulin. About 45,000 and 25,000 cells were initially seeded in experiments 1 and 2, respectively. Each point is mean of triplicate wells $\times 10^{5} \pm \mathrm{SD}$.

Insulin treatment of the cells did not alter the recovery of medium glucose as compared with control medium from untreated cells. Higher concentrations of glucose $(>210 \mathrm{mg} / \mathrm{dl})$ actually suppressed cell growth and were therefore not able to be tested.

To ascertain whether the observed effects of insulin on GH secretion were related to a metabolic effect of insulin on cellular glucose consumption, cells were tested in giucose-free medium containing either added glucose, 2-deoxy-glucose and Na-pyruvate, Na-pyruvate, or glutamine (Table III). For these experiments, cells which had either been pretreated with insulin (3.5 $\mathrm{nM}$ ) for $72 \mathrm{~h}$ or not (controls) were plated into multiwells containing normal culture medium. After $24 \mathrm{~h}$, this medium was aspirated and replaced with glucose-free medium containing the respective substrate and cells exposed to insulin and/or hydrocortisone for the ensuing $3 \mathrm{~d}$.

Hydrocortisone ( 0.1 and $1 \mu \mathrm{M})$ stimulated GH secretion 35-fold in these experiments, but only a doubling of GH was seen when cells growing in glucose-free medium containing $\mathrm{Na}$ pyruvate and dialyzed horse serum $(10 \%)$ were exposed to the steroid (Table III). Nevertheless, insulin ( $3.5 \mathrm{nM})$ clearly suppressed hydrocortisone-induced GH secretion by at least half in the presence of all four substrates tested. Basal GH secretion was lower in cells exposed to 2-deoxyglucose (the cell number

Table II. Glucose Concentrations in Culture Medium

\begin{tabular}{lcc}
\hline \multicolumn{3}{c}{ Medium glucose $(\mathrm{mg} / \mathrm{dl})^{*}$} \\
\hline & Recovered & \\
\cline { 2 - 3 } Starting & Control & Insulin-treated \\
\hline 110 & $86 \pm 4$ & $90 \pm 2$ \\
160 & $136 \pm 4$ & $136 \pm 3$ \\
210 & $174 \pm 6$ & $182 \pm 5$ \\
\hline
\end{tabular}

* Mean \pm SD of triplicate wells incubated for $4 \mathrm{~d}$ in the presence or absence (controls) of insulin ( $7 \mathrm{nM}$ ). Differences in glucose measured in control and insulin-treated wells were not significant for any of the three glucose doses. in this group was about $50 \%$ of glucose-treated values), nevertheless this was halved by insulin $(P<0.025)$. 2-deoxyglucosetreated cells responded to hydrocortisone with an almost 3-fold increase in GH secretion and this was clearly suppressed by insulin $(P<0.001)$.

Effects of insulin-like growth factor. In order to assess the effects of insulin-like growth factors on the $\mathrm{GH}$ response in these cells, they were exposed to varying doses of a partially purified somatomedin preparation containing IGF-I $(0-500 \mathrm{ng} / \mathrm{ml})$ for $4 \mathrm{~d}$. The dose response shown in Fig. 7 shows that maximal ( $\sim 60 \%$ of controls) inhibition of $\mathrm{GH}$ secretion was achieved by $250 \mathrm{ng} / \mathrm{ml}$ of IGF-I. Although IGF-I $(100 \mathrm{ng} / \mathrm{ml})$ suppressed basal GH secretion to $70 \%$ of controls $(P<0.05)$, no suppression of hydrocortisone-stimulated GH secretion was seen (Table IV). Similarly, IGF-I did not reverse the suppression of PRL induced by hydrocortisone (Table IV). No differences in results were observed when these experiments were repeated twice on cells which had been pretreated with the respective dose of IGF-I for $72 \mathrm{~h}$.

\section{Discussion}

These experiments demonstrate a direct inhibitory effect of insulin on basal and hydrocortisone-stimulated GH secretion by $\mathrm{GH}_{3}$ rat pituitary tumor cells. The suppressive effects of insulin on GH secretion appear to be unrelated to glucose utilization by the cells.

The intracellular turnover of $\mathrm{GH}$ and PRL by $\mathrm{GH}_{3}$ cells is extremely rapid ( $<60 \mathrm{~min}$ ) and the cells do not store large pools of intracellular growth hormone $(13,18,33)$. Therefore, hormone release into the medium during these longer-term incubations may be regarded as a true reflection of hormone synthesis (18). Extracellular effects of insulin on GH stability during the timecourse of these experiments were excluded, inasmuch as ${ }^{125} \mathrm{I}$ GH tracer remained stable in the presence of insulin under experimental conditions.

The specificity of the $\mathrm{GH}$ response to insulin was suggested by the observation that insulin did not significantly alter basal $\mathrm{GH}_{3}$ cell replication, nor did insulin antagonize the hydrocor- 
Table III. Effects of Insulin on GH Secretion (nanograms per $10^{6}$ cells) by Cells Grown in Glucose-free Medium for $3 d$

\begin{tabular}{|c|c|c|c|c|c|}
\hline \multirow[b]{2}{*}{ Experiment } & \multirow[b]{2}{*}{ Added substrate } & \multirow[b]{2}{*}{ Insulin } & \multicolumn{3}{|c|}{ Hydrocortisone } \\
\hline & & & 0 & 1 & 0.1 \\
\hline & & $n M$ & $\mu M$ & $\mu M$ & $\mu M$ \\
\hline \multirow[t]{3}{*}{ I } & Glucose $(100 \mathrm{mg} / \mathrm{dl})$ & 0 & $1167 \pm 64$ & $4210 \pm 225$ & $5411 \pm 850$ \\
\hline & & 3.5 & $706 \pm 129$ & $1705 \pm 294$ & $1681 \pm 177$ \\
\hline & & $P$ & $<0.025$ & $<0.005$ & $<0.01$ \\
\hline \multirow[t]{3}{*}{ II } & 2-deoxyglucose $(20 \mathrm{mg} / \mathrm{dl})$ & 0 & $78 \pm 8$ & $224 \pm 13$ & $22 i \pm 8$ \\
\hline & and Na-pyruvate (10 mM) & 3.5 & $38 \pm 9$ & $62 \pm 6$ & $59 \pm 2$ \\
\hline & & $P$ & $<0.025$ & $<0.001$ & $<0.001$ \\
\hline \multirow[t]{3}{*}{ III } & Na-pyruvate (10 mM) & 0 & $998 \pm 133$ & $2001 \pm 296$ & $1404 \pm 157$ \\
\hline & & 3.5 & $446 \pm 138$ & $671 \pm 108$ & $755 \pm 78$ \\
\hline & & $P$ & $<0.025$ & $<0.01$ & $<0.02$ \\
\hline \multirow[t]{3}{*}{ IV } & Na-pyruvate (10 mM) & 0 & $1090 \pm 9$ & $3888 \pm 523$ & $5053 \pm 296$ \\
\hline & & 3.5 & $741 \pm 102$ & $1417 \pm 156$ & $1436 \pm 103$ \\
\hline & & $\dot{P}$ & $<0.02$ & $<0.01$ & $<0.001$ \\
\hline \multirow[t]{3}{*}{$\mathbf{v}$} & Glutamine (10 mM) & 0 & $1700 \pm 16$ & $6010 \pm 274$ & $4283 \pm 284$ \\
\hline & & 3.5 & $1374 \pm 71$ & $3312 \pm 562$ & $2512 \pm 218$ \\
\hline & & $P$ & $<0.01$ & $<0.01$ & $<0.01$ \\
\hline
\end{tabular}

$\mathrm{GH}_{3}$ cells were grown in normal culture medium for $24 \mathrm{~h}$, whereafter medium was aspirated and replaced with glucose-free medium (deficient Dulbecco's Modified Eagle medium, dialyzed horse serum (10\%), glutamine (5 mM), and antibiotics), replenished with either glucose, 2-deoxyglucose and Na-pyruvate, Na-pyruvate, or glutamine as indicated. In experiment IV, horse serum (10\%) was nondialyzed. Each value represents mean \pm SEM of at least triplicate wells.

tisone-induced suppression of cell growth. Kiino and Dannies (34), in fact, showed a slight decrease in the rate of $\mathrm{GH}_{4} \mathrm{C}_{1}$ cell replication in the presence of insulin and estradiol.

The time course of the insulin-induced effects on these ex-

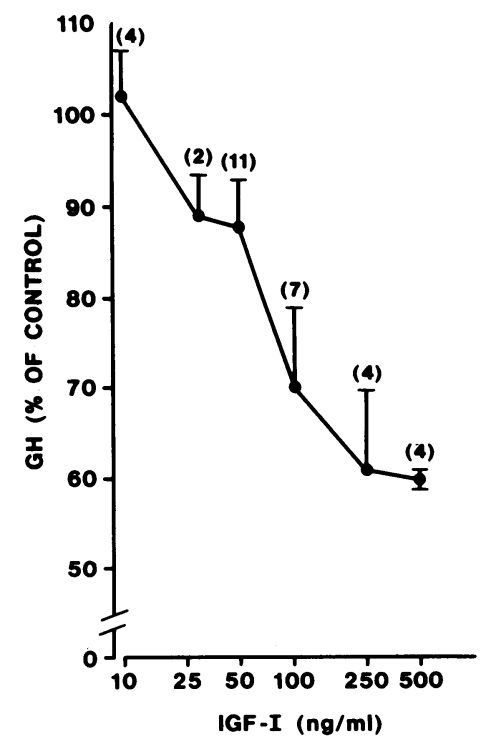

Figure 7. Dose response of inhibition of GH secretion by IGF-I. Cells were incubated for $4 \mathrm{~d}$ in the presence of the indicated doses of IGF-I. Figures in parentheses indicate total number of wells in each group. Data were pooled from four independent experiments. Secretion of $\mathrm{GH}$ in 16 control wells was $1030 \pm 321 \mathrm{ng} / 10^{6}$ cells (mean \pm SEM). periments had a lag period of $48 \mathrm{~h}$. When insulin was added to rat anterior pituitary incubations, for $3 \mathrm{~h}$, no changes in incorporation of ${ }^{14} \mathrm{C}$-lysine into the $\mathrm{GH}$ peak on polyacrylamide gel electrophoresis was noted (9). This relatively short incubation

Table IV. Effects of IGF on Hydrocortisone (1 $\mu M)$-mediated GH and PRL Secretion

\begin{tabular}{lll}
\hline & GH$^{*}$ & PRL $^{*}$ \\
\hline $\begin{array}{l}\text { Controls } \\
(12)\end{array}$ & $451 \pm 21$ & $36 \pm 10$ \\
$\begin{array}{l}\text { IGF-I }(50 \mathrm{ng} / \mathrm{ml}) \\
\quad(9)\end{array}$ & $455 \pm 50$ & $40 \pm 12$ \\
$\begin{array}{l}\text { IGF-I }(100 \mathrm{ng} / \mathrm{ml}) \\
(7)\end{array}$ & $652 \pm 24$ & $33 \pm 3$ \\
\hline
\end{tabular}

* Percent of hormone secretion by control wells not exposed to hydrocortisone or IGF.

Cells were treated as indicated for $5 \mathrm{~d}$. GH and PRL values (mean \pm SEM) from three independent experiments were pooled and normalized as a percentage of mean hormone secretion by at least triplicate control wells not exposed to hydrocortisone or IGF in each experiment. Secretion of GH and PRL in 19 such control wells was $1188 \pm 129$ and $11778 \pm 593 \mathrm{ng} / 10^{6}$ cells, respectively. 
time may have precluded the observation of insulin effects on protein synthesis.

Most of the cellular effects of insulin appear to be mediated by a specific surface receptor possessing a $K_{\mathrm{D}}$ of about $1 \mathrm{nM}$ (14). Insulin receptors have been characterized on pituitary cells and their $K_{\mathrm{D}}$ was $2-0.3 \mathrm{nM}(12,13) . \mathrm{GH}_{3}$ cells were reported to contain 10,000 specific binding sites per cell (12). The concentration of insulin employed here, which achieved maximal GH suppression, correlated well with the observed affinity of insulin for the $\mathrm{GH}_{3}$ cell receptor.

Although insulin antiserum was able to block the inhibitory effects of insulin on GH secretion, an effect of insulin mediated via an insulin-like growth factor receptor (35) is unlikely at the doses employed. Usually, much larger doses of insulin than those employed here are necessary to activate other growth factor receptors and responses (36-40). The dose response of GH suppression by insulin clearly differs from that of IGF-I in these cells. Both structural and functional homology of insulin, IGFI and IGF-II, and their respective receptors do exist (3), but the affinity of these compounds for each others' receptors differ markedly. Half-maximal displacement of ${ }^{125}$ I-IGF-I from IGFI receptors on IM-9 lymphocytes was achieved by $3.6 \mathrm{nM}$ IGFI and only by $500 \mathrm{nM}$ insulin (38). In the experiments using IGF, the suppression of basal GH secretion was only achieved by relatively high doses of IGF-I ( $100 \mathrm{ng} / \mathrm{ml}$ or about $13 \mathrm{nM})$. Furthermore, IGF did not inhibit the hydrocortisone-stimulated GH secretion nor did it reverse the suppression of PRL caused by the steroid. Insulin, at lower doses on a molar basis, clearly reversed both the GH and PRL changes induced by hydrocortisone.

Somatomedin-C (equivalent to IGF-I, $25 \mathrm{ng} / \mathrm{ml}$ ), but not proinsulin, inhibited dibutyryl-cyclic AMP(dbCAMP)-stimulated $\mathrm{GH}$ release by primary cultures of rat pituitary cells by $\sim 90 \%$ during a 24-h incubation but had no effect after $4 \mathrm{~h}$ (41). Somatomedin-C did not alter basal GH secretion. In this interesting study, a dual feedback of somatomedin-C on both the hypothalamus and pituitary was described. When a similar dose of porcine insulin $(25 \mathrm{ng} / \mathrm{ml})$ was tested, it did not suppress basal GH but did inhibit the dbCAMP-stimulated GH secretion by $35 \%$ during $24 \mathrm{~h}(41)$. Lower doses of insulin were not tested. The dose of insulin used was equivalent to almost $4.2 \mathrm{nM}$, which is about sixfold greater than the dose of bovine insulin required in these studies to achieve about $50 \%$ inhibition of basal $\mathrm{GH}$ secretion by $\mathrm{GH}_{3}$ pituitary tumor cells.

The suppressive effects of IGF-I on basal GH secretion by $\mathrm{GH}_{3}$ cells were observed at higher doses than those employed in a recent study showing that $0.5-10 \mathrm{ng} / \mathrm{ml}$ IGF-I was required to inhibit both basal and growth hormone-releasing factor-stimulated GH secretion by rat pituitary cells (42). In the latter study, effects of insulin were not reported. The discrepancies in responses of basal in vitro GH secretion to somatomedin treatment $(41,42)$ as well as the differing dose requirements in the latter two studies and the present study may possibly be ascribed to the different somatomedin preparations used in all three studies, and also to the fact that the previous two studies employed primary rat pituitary cultures, whereas in the present study a rat cell line was used. In vivo studies have indicated a suppressive effect of intracerebral IGFs on GH secretion (43).

Hydrocortisone has been shown to stimulate $\mathrm{GH}(17,18)$ and suppress PRL (19) in these pituitary cells, i.e., effects opposite to those observed for insulin in these experiments. Cortisol also stimulated GH secretion by monkey pituitary tissue (44). Dexamethasone has also been shown to stimulate pituitary GH gene transcription in vivo (24), and to enhance pituitary $\mathrm{GH}$ response to growth hormone-releasing factor (45). These experiments confirm that hydrocortisone stimulates $\mathrm{GH}$ and inhibits PRL secretion. The stimulation of $\mathrm{GH}$ secretion by $\mathrm{GH}_{3}$ cells was shown to be independent of glucose utilization since it seemed to occur equally well in the presence or absence of glucose. This is in agreement with previous findings (46). In the present studies, insulin suppressed this enhanced GH secretion regardless of the presence of glucose in the medium. The basal secretion of $\mathrm{GH}$ was far lower in the cells exposed to 2-deoxyglucose (Table III) than in the other groups. Cell replication was also far slower in these cells, consistent with previously described effects of 2deoxyglucose on GH cells (46). Nevertheless, the effects of insulin and hydrocortisone were observed regardless of the varying basal GH secretion in the different groups. Insulin is known to antagonize other cellular effects of hydrocortisone, especially in liver (47), adipose (47), and lung tissue (48). Interestingly, there has also been a preliminary report that dexamethasone increases the number of insulin receptors on $\mathrm{GH}_{1}$ cells (12). In an earlier study using $\mathrm{GH}_{1}$ cells, low doses $(5-50 \mathrm{ng} / \mathrm{ml})$ of insulin actually potentiated the $\mathrm{GH}$ response to cortisol (49). The induction of rat $\mathrm{GH}$ protein synthesis by dexamethasone $(1 \mu \mathrm{M})$ in $\mathrm{GC}$ and $\mathrm{GH}_{3}$ cells grown in a chemical defined serum-free medium (50) was inhibited by relatively high concentrations of insulin (10 $\mathrm{ug} / \mathrm{ml}$ ) added to the medium for at least $48 \mathrm{~h}$. Insulin, in this system, inhibited the steroid inducibility of both rat $\mathrm{GH}$ and p16 protein synthesis as visualized by two-dimensional gel electrophoresis, but had no effect on the suppression of rat PRL synthesis caused by dexamethasone treatment of the cells. In the present studies, insulin was able to inhibit the effects of up to $1 \mu \mathrm{M}$ hydrocortisone by $>30 \%$. That these effects were specific for hormone gene expression was confirmed by two other observations. First, insulin did not alter the suppressed $\mathrm{GH}_{3}$ cell replication rate induced by hydrocortisone. The inhibitory effect of hydrocortisone on cell replication and total protein synthesis has been described in previous studies $(17,18)$. Using $\mathrm{GH}_{1}$ cells, however, both low $(5-50 \mathrm{ng} / \mathrm{ml})$ and very high $(2.5 \mu \mathrm{g} / \mathrm{ml})$ doses of porcine insulin did stimulate the suppressed $\left[{ }^{3} \mathrm{H}\right]$ thymidine incorporation caused by cortisol, while intermediate doses had no effect (49). Although insulin antagonized lecithin synthesis induced by cortisol in fetal lung cells, it also did not alter the inhibition of lung cell growth induced by cortisol (48). Secondly, insulin also reversed the suppression of PRL secretion induced by hydrocortisone (Fig. 6). In fact, the basal PRL secretion by $\mathrm{GH}_{3}$ cells was markedly stimulated by over $50 \%$ in the presence of insulin and no added hydrocortisone. This is in agreement with similar previous observations where exposure of rat pituitary 
tumor cells to insulin $\left(1.8 \times 10^{-7} \mathrm{M}\right)$ and estrogens caused increased intracellular PRL concentrations in $\mathrm{GH}_{4} \mathrm{C}_{1}$ rat pituitary tumor cells (34), and this effect was not due to any cell cycle changes induced by insulin (51).

The discordant response of GH and PRL to insulin is further evidence for independent hormonal control of GH and PRL secretion by $\mathrm{GH}_{3}$ cells $(13,15)$, although a reciprocal linkage cannot be excluded.

The results shown in this study as well as the inhibitory effect of insulin on GH gene expression (50) and on dbCAMPstimulated GH secretion (41) suggest that insulin may play a specific direct negative feedback role on $\mathrm{GH}$ secretion.

\section{Acknowledgments}

The author is grateful to Marilyn Leung and Judy Berlfein for superb technical assistance, to Bob Karjala for performing the insulin RIA, to Dr. Mayer B. Davidson for reviewing the manuscript, and to Helene Zauderer for secretarial assistance.

This work was supported in part by a Feasibility Grant from the American Diabetes Association.

\section{References}

1. Roth, J., S. M. Glick, R. S. Yalow, and S. A. Berson. 1963. Secretion of human growth hormone: physiologic and experimental modification. Metab. Clin. Exp. 12:577-579.

2. Cryer, P. E., and W. H. Daughaday. 1977. Growth hormone. In Clinical Neuroendocrinology. L. Martini, and G. M. Besser, editors. Academic Press, New York. 243-277.

3. Czech, M. P. 1982. Structural and functional homologies in the receptors for insulin and the insulin-like growth factors. Cell. 31:8-10.

4. Wool, I. G., and M. E. Krahl. 1959. An effect of insulin on peptide synthesis independent of glucose or amino-acid transport. Nature (Lond.). 183:1399-1400.

5. Lukens, F. D. W. 1964. Insulin and protein metabolism. Diabetes. 13:451-461.

6. Krahl, M. E. 1974. Endocrine function of the pancreas. Annu. Rev. Physiol. 36:331-360.

7. Goodner, C. J., and N. Freinkel. 1961. Studies of anterior pituitary tissue upon carbohydrate metabolism. J. Clin. Invest. 40:261-272.

8. Hazelwood, R. L., and B. S. Hazelwood. 1964. Influence of alloxan diabetes on growth hormone content of the rat hypophysis. Am. J. Physiol. 206:1137-1144.

9. Goodner, C. J., and M. D. Krouse. 1972. Studies of the effect of insulin on synthesis of electrophoretically separated proteins in anterior pituitary in vitro. Endocrinology. 90:1639-1642.

10. Havrankova, J., J. Roth, and M. Brownstein. 1978. Insulin receptors are widely distributed in the central nervous system of the rat. Nature (Lond.). 272:827-829.

11. Turyn, D., and J. M. Dellacha. 1980. Insulin binding sites in rat hypophysis. IRCS (Int. Res. Comm. Syst.) Med. Sci. Libr. Compend. 8:580-581.

12. Hollander, P., F. Stanley, and H. H. Samuels. 1979. Thyroid and glucocorticoid hormones induce insulin receptors and inhibit insulin degradation in cultured GH cells. Endocrine Society 61st Annual Meeting. Abstract 497.
13. Bancroft, F. C. 1981. Function cell lines of rat pituitary tumor cells. In Functionally Differentiated Cell Lines. G. Sato, editor. A. R. Liss, New York. 47-59.

14. Czech, M. P. 1982. Cellular dynamics of insulin action. Fed. Proc. 41:2717-2718.

15. Tashjian, A. H., Jr., Y. Yasumura, L. Levine, G. H. Sato, and M. L. Parker. 1968. Establishment of clonal strains of rat pituitary tumor cells that secrete growth hormone. Endocrinology. 82:342-351.

16. Tashjian, A. H. 1979. Clonal strains of hormone-producing pituitary cells. Methods Enzymol. 58:527-536.

17. Kohler, P. O., L. A. Frohman, W. E. Bridson, T. Vanha-Pertula, and J. M. Hammond. 1969. Cortisol induction of growth hormone synthesis in a clonal line of rat pituitary tumor cells in culture. Science (Wash. DC). 166:633-634.

18. Bancroft, F. C., L. Levine, and A. H. Tashjian, Jr. 1969. Control of growth hormone production by a clonal strain of rat pituitary cells: stimulation of hydrocortisone. J. Cell Biol. 43:432-441.

19. Tashjian, A. H., Jr., F. C. Bancroft, and L. Levine. 1970. Production of both prolactin and growth hormone by clonal strain of rat pituitary tumor cells: differential effects of hydrocortisone and tissue extracts. J. Biol. Chem. 47:61-70.

20. Martial, J. A., J. D. Baxter, H. M. Goodman, and P. H. Seeburg. 1977. Regulation of growth hormone messenger RNA by thyroid and glucocorticoid hormones. Proc. Natl. Acad. Sci. USA. 74:1816-1820.

21. Shapiro, L. E., H. H. Samuels, and B. M. Yaffe. 1978. Thyroid and glucocorticoid hormones synergistically control growth hormone mRNA in cultured GH cells. Proc. Natl. Acad. Sci. USA. 75:45-49.

22. Dobner, P. R., E. S. Kawasaki, L. Y. Yu, and F. C. Bancroft. 1981. Thyroid or glucocorticoid hormone induces pregrowth hormone mRNA and its probable nuclear precursor in rat pituitary cells. Proc. Natl. Acad. Sci. USA. 78:2230-2234.

23. Wegnez, M., B. S. Schachter, J. D. Baxter, and J. A. Martial. 1982. Hormonal regulation of growth hormone mRNA. DNA (NY). 1:145-153.

24. Evans, R. M., N. C. Birnberg, and M. G. Rosenfeld. 1982. Glucocorticoid and thyroid hormones transcriptionally regulate growth hormone gene expression. Proc. Natl. Acad. Sci. USA. 79:7659-7663.

25. Rosenfeld, R. G., and L. A. Dollar. 1982. Characterization of the somatomedin C. Insulin-like growth factor I (SM-C IGF-I) receptor on cultured human fibroblast monolayers: regulation of receptor concentrations by SM-C/IGF-I and insulin. J. Clin. Endocrinol. Metab. 55:434-440.

26. Furlanetto, R. W., L. E. Underwood, J. J. Van Wyk, and A. J. D'Ercole. 1977. Estimation of somatomedin-C levels in normals and patients with pituitary disease by radioimmunoassay. J. Clin. Invest. 60:648-656.

27. Hintz, R. L., and F. Liu. 1982. A radioimmunoassay for IGFII specific for the C-peptide region. J. Clin. Endocrinol. Metab. 54:442446.

28. Melmed, S., M. Nelson, N. Kaplowitz, T. Yamada, and J. M. Hershman. 1981. Glutathione-dependent T4 5'monodeiodination modulates growth hormone production by cultured non-thyrotropic rat pituitary cells. Endocrinology. 108:970-976.

29. Davidson, M. B., and S. Melmed. 1983. Hepatocyte insulin binding and action in rats with somatomammotrophic tumours. Diabetologia. 25:60-65.

30. Davidson, M. B., and V. Venkatasian. 1982. Persistence of a curvilinear scatchard plot for insulin binding despite correction for degradation. Metab. Clin. Exp. 31:1206-1209.

31. Greenwood, F. C., W. M. Hunter, and J. S. Grover. 1963. The 
preparation of ${ }^{131}$ I-labelled human growth hormone of high specific activity. Biochem. J. 89:114-123.

32. Winer, B. J. 1971. Statistical Principals in Experimental Design. McGraw-Hill, New York. 2nd ed.

33. Stachura, M. E. 1982. Sequestration of an early-release pool of growth hormone and prolactin in $\mathrm{GH}_{3}$ rat pituitary tumor cells. Endocrinology. 111:1769-1777.

34. Kiino, D. R., and P. S. Dannies. 1981. Insulin and 17-beta estradiol increase the intracellular prolactin content of $\mathrm{GH}_{4} \mathrm{C}_{1}$ cells. Endocrinology. 109:1264-1269.

35. Rechler, M. M., and S. P. Nissley. 1977. Somatomedins and related growth factors. Nature (Lond.). 270:665-666.

36. Van Wyk, J. J., L. E. Underwood, R. L. Hintz, D. R. Clemmons, S. J. Voina, and R. P. Weaver. 1974. The somatomedins: a family of insulin-like hormones under growth hormone control. Recent Prog. Horm. Res. 30:259-298.

37. Rosenfeld, R. G., and R. L. Hintz. 1980. Characterization of a specific receptor for somatomedin C (SM-C) on cultured human lymphocytes: evidence that SM-C modulates homologous receptor concentration. Endocrinology. 107:1841-1850.

38. Rosenfeld, R. G., R. L. Hintz, and L. A. Dollar. 1982. Insulininduced loss of insulin-like growth factor-1 receptors on IM-9 lymphocytes. Diabetes. 31:375-381.

39. Kasuga, M., E. Van Obberghen, S. P. Nissley, and M. M. Rechler. 1981. Demonstration of two subtypes of insulin-like growth factor receptors by affinity cross-linking. J. Biol. Chem. 256:5305-5308.

40. Monier, S., A. L. Cam, and Y. L. M. Brulstel. 1983. Insulin and insulin-like growth factor: effects on protein synthesis in isolated muscles from lean and goldthioglucose-obese mice. Diabetes. 32:392-397.

41. Berelowitz, H., M. Szabo, L. A. Frohman, S. Firestone, L. Chu, and R. L. Hintz. 1981. Somatomedin-C mediates growth hormone negative feedback by effects on both the hypothalamus and the pituitary. Science (Wash. DC). 212:1279-1281.
42. Brazeau, P., R. Guillemin, N. Ling, J. Van Wyke, and R. Humbel. 1982. Inhibition par les somatomédines de la sécretion de l'hormone de croissance stimulee par le facteur hypothalamique somatocrinine (GRF) on le peptide de synthèse hpGRF. Comptus. Rende. Acad. Sci. Paris. 295:651-654.

43. Tannenbaum, G. S., H. J. Guyda, and B. I. Posner. 1983. Insulinlike growth factors: a role in growth hormone negative feedback and body weight regulation via brain. Science (Wash. DC). 220:77-79.

44. Kohler, P. O., W. E. Bridson, and P. L. Rayford. 1968. Cortisol stimulation of growth hormone production by monkey adenophyophysis in tissue culture. Biochem. Biophys. Res. Commun. 33:834-838.

45. Wehrenberg, W. B., A. Baird, and N. Ling. 1983. Potent interaction between glucocorticoids and growth hormone-releasing factor in vivo. Science (Wash. DC). 221:556-558.

46. Tashjian, A. H., and R. F. Hoyt. 1971. Transient controls of organ specific functions in pituitary cells in culture. In Molecular Genetics and Developmental Biology. M. Sussman, editor. Prentice-Hall, NJ. 353-387.

47. J. D. Baxter. 1976. Glucocorticoid hormone action. Pharmacol. Ther. 2:605-659.

48. Smith, B. T., C. J. P. Giroud, M. Robert, and M. E. Avery. 1975. Insulin antagonism of cortisol action on lecithin synthesis by cultured fetal lung cells. J. Pediatr. 87:953-955.

49. Pertulla, T. V., P. O. Kohler, and L. A. Frohman. 1970. Effects of insulin on growth hormone induction by cortisol in rat pituitary tumor cells. Life Sci. 9:805-813.

50. Ivarie, R. D., J. D. Baxter, and J. A. Morris. 1981. Interaction of thyroid and glucorticoid hormones in rat pituitary tumor cells: specificity and diversity of the responses analyzed by two-dimensional gel electrophoresis. J. Biol. Chem. 256:4520-4528.

51. Kiino, D. R., D. E. Burger, and P. S. Dannies. 1982. Prolactin storage in a clonal strain of rat pituitary tumor cells is cell-cycle dependent. J. Cell Biol. 93:459-462. 